FACTA UNIVERSITATIS

Series: Philosophy, Sociology, Psychology and History Vol. 17, Nº 2, 2018, pp. 127 - 135

https://doi.org/10.22190/FUPSPH1802127D

Original Scientific Paper

\title{
COMMERCE AND CUSTOMS SERVICE \\ ON THE OTTOMAN-HABSBURG BORDER IN THE FIRST HALF OF THE $18^{\text {TH }}$ CENTURY
}

UDC 94(560:436-89):336.41"17"

\section{Miloš Đorđević, Slaviša Nedeljković}

University of Niš, Faculty of Philosophy, Department of History, Serbia

\begin{abstract}
In the year of the $300^{\text {th }}$ anniversary of the Treaty of Passarowitz (Treaty of Požarevac) (1718), this paper has the goal of providing so far unknown facts regarding commerce and the organization of customs service in what was the recently founded Austrian province, the Kingdom of Serbia. The distribution of income from customs duties was in the hands of the Chief customs authority of Belgrade. That income covered expenses of its operations and filled the coffers of the Administration. Working methods for customs officers were regulated by special bylaws of the emperor Charles (Karl) VI that specified the application of customs tariffs, procedures applied in charging customs duties, introduction of privileged positions for Oriental company, and the implementation of protection measures against the plague at the border with the Ottoman Empire.
\end{abstract}

Key words: Habsburg Monarchy, customs, commerce, Ottoman Empire, Belgrade administration.

\section{INTRODUCTION}

The border between the Ottoman and Habsburg empires was the first defense frontline in a long struggle to defend European countries. For more than 350 years the system comprising military and civilian authorities successfully functioned along a changing borderline, part of which went through Serbia (On the borderline between Ottoman empire and Habsburg monarchy see: Barkey 2008; Ágoston 2015; Ingrao 1994; Abou-el-Haj 1969; Baramova 2015). In wartime, the military border (military frontier) since the $16^{\text {th }}$ century served as a shield against Ottoman raids, and in $17^{\text {th }}$ century it was also charged with the prevention of the spreading of communicable diseases (primarily the plague) from the Ottoman Empire (On prevention of plague epidemic at Austro-Turkish border see: Balazs

Received May 30, 2018 / Accepted October 14, 2018

Corresponding author: Miloš Đorđević

University of Niš, Faculty of Philosophy, Cirila i Metodija 2, 18000 Niš, Serbia

E-mail: milos.djordjevic@ filfak.ni.ac.rs 
and Foley 2010; Jesner 2015; Kocić i Dajč 2014; Pešalj 2005; Samaržija 2013). After the Austro-Turkish War of 1716-1718 the Habsburg Monarchy conquered the territory south of the Sava and Danube and divided it into districts that made a newly formed province - the Kingdom of Serbia. The temporary Austrian military administration lasted until 1720 when it was replaced by the administration of Kingdom of Serbia or Belgrade Administration composed of representatives of the Court War Council and the Court Chamber. The Chamber part, in accordance with its structure, took over the business side of things, with parts related to income forming separate divisions or sections, where the Chief customs authority was one of them. The Chief customs authority had its seat in Belgrade, and outposts throughout the country: Palež, Grocka, Smederevo, Požarevac, Veliko Gradište, Paraćin, Vitanovac, Čačak, Rudnik, Valjevo, Crna Bara and Šabac (Pecinjački 1983, 76; Hajek 1912, 27-29; Đorđević 2012, 186).

\section{Customs SERVICE}

Continuing the practices of his predecessors (see: von Peez 1918), the emperor Charles VI wanted to revive trade with the East through a society for commerce with the Levant when he issued a decree [OeStA/FHKA SUS Patente 52.21 (May 27, 1719)] of May 27, 1719 that announced the formation of the "Imperial Privileged Oriental Company" [OeStA/FHKA SUS Patente 52.14. (May 20, 1722)]. With it he did not relinquish the basic postulates formulated by the Austrian industrialist Johann Joachim Becher in his "Political Discourse" (Politische Discurs) in 1668, which stated that employing and keeping population figures is more important than the quantity of gold that a state obtains in a trade exchange (Tschugguel 1996, 8; Hassinger 1951; Živojinović 2000, 152-153). But increase of state income as a goal requires not only the development of agriculture and traffic and stimulating manufacture, but also the acquisition of new markets.

Customs officers that received posts in the Kingdom of Serbia in most cases had previous experience in performing similar duties. Quite a lot of them were brought from the ranks of the administrative apparatus of the Habsburg Monarchy, those that had previously served in Hungary and Slavonia. Such people in responsible positions in the Chief Customs Authority were considered the best solution for the functioning of the service on the border with the Ottoman Empire. Depending on their position and the job they performed, they received an annual salary of 60 to 700 forints (Pecinjački 1980, 102; Idem 1983, 106-109).

In each customs outpost, affairs were run by a manager (Einnehmer) posted by the Court Chamber and it was not unusual for him to be the headmaster of the district where the customs outpost was situated (Pecinjački 1983, 102-105). Controllers of the customs-monopoly were named by the Imperial Bank Institution (Kayserlicher Universall Bancalität), and in addition, object reviewers (Aufschauer/Beschauer) and supervisors (Überreiter), liaison officers in customs service and headmaster assistants were also engaged. Stated as one of the principal sources of financing of the Belgrade Administration was payment of a certain lease by customs services, and on average it annually made one third of the Administration income (Pecinjački 1983, 76). After payment of the lease, the chief customs authority had the liberty to spend the rest of the money from customs duties as it saw fit. Anyway, reports, proposals and instructions that kept coming from the Chamber authority of Belgrade Administration had a substantial effect on the overall sum realized from custom duties. That is primarily true in 
the case of determining customs tariffs for goods that were imported, exported or were in transit through the Kingdom of Serbia [OeStA/FHKA SUS Patente 65.2 (1733)]. Customs tariffs for the Kingdom of Serbia were almost exactly the same as those in other Newly acquired lands (Neoacquistica), proving that the fiscal policy of the Habsburg Monarchy was uniform. That confirms not only that the first step was made towards forming uniform customs area in the mentioned lands, but also that the border customs system towards the Ottoman Empire was homogenous, with no different custom tariffs, as those known in the hereditary lands of the Habsburg Monarchy. That process of nationalizing customs with the help of customs officers started to develop throughout the Monarchy at the time of Charles VI and empress Maria Theresa, and lasted all the way to the introduction of a general tax on expenditure in 1829 (Hassinger 1987, 17).

Depending on whether a certain product was considered important for the trade and finances of the Habsburg Monarchy or whether the value of certain imported luxury goods was enormous, a percentage of the value of the product imported or exported that the empire merchant paid to the customs varied from $0,1 \%$ to $40 \%$. Customs officers had all the necessary information in their tariff table regarding which tariff to apply for certain goods. Along with every product listed, there was a percentage to be charged to the imperial subject for export, import and in some cases transit customs duty. Besides, for some products the origin, size (length, width, weight) of that product was significant and how it had to be measured were also listed. The next column provided the value of the product, and the charge that applied to Ottoman subjects who paid all duties at the level of 3\% of the total value of the article. The last three columns presented the calculated amounts of import, export and transit customs duties, expressed in forints and kreuzers to be paid by imperial subjects [OeStA/FHKA SUS Patente 65.2 (1733)].

\section{MEASURES OF CROSS-Border TRADE}

The contract on trade and navigation of July 27,1718 , signed at the end of the peace congress in Passarowitz, as a basis for economic policy, had special significance for the Habsburg Monarchy. Although imperial merchants paid lower tariffs for many products (mostly $1 \%$ or $2 \%$ ), for them it was just one of the tariffs they had to pay in case they send the merchandise, for instance, to an annual fair outside of the Kingdom of Serbia, while the first paid customs duty for an Ottoman was also the last one in the Habsburg Monarchy. Their situation improved a little when a decree of the Court Chamber in Vienna of February 12, 1731 introduced a uniform customs charge rate of $6 \%$ for all customs posts in Hungary and Newly acquired lands, regardless of whether the merchandise was imported into the Monarchy or exported to the Ottoman Empire. That type of convenience was mostly used by merchants from hereditary lands that kept trade connections with Ottoman merchants, and those from the Kingdom of Serbia who sold "Turkish goods" at annual fairs (Langer 1889, 214; Popović 1950, 92).

The absence of customs records and sources related to customs income, except for fragments from the customs outpost in Paraćin (Compare: Gavrilović 2008) and some for the outpost Radojevac that belonged to the Banat Administration (Compare: Pecinjački 1972, 101-103), for the entire time of the Austrian administration of Serbia posed as a big problem in establishing the total amount accumulated from customs fares, and the intensity of trade that certainly varied due to plague epidemics and prevention measures 
of Austrian authorities at the border with the Ottoman Empire. Nevertheless, data on customs income and expenditure for a three-year period 1730-1732 give insight into the details regarding the organization of customs authority. Of all the customs houses in the Kingdom of Serbia, the one in Belgrade had the largest income (Pecinjački 1972, 79-83). That is understandable, having in mind that Belgrade was the chief point that managed other customs outposts and that it had the largest concentration of population in the Kingdom of Serbia. Income consisted of the regular collection of customs duties or taxes (Mauth-Geföhlen) that accounted for the majority of income, then taxes for imported wine (Wein Aufschlag), charges for the use of rafts and bridges (Bryck Mauth and Überfuhr Geföhlen), road tolls (Steeg Recht) and contraband (Contraband) (Pecinjački 1972, 81). Each of these customs incomes was displayed separately in the records, and the customs houses delivered those records to the chief customs authority in most cases quarterly (see: Pecinjački 1983).

Expenditures of custom houses were managed by the chief customs authority in Belgrade. The biggest expenditure of the chief customs authority was payment of the lease to the Belgrade Administration and it amounted to 28,900 forints annually, or 7,225 forints quarterly (Pecinjački 1983, 105-106). Current expenses necessary for customs house operations were the purchase of rafts and other vessels, buy-out of vehicles, unplanned and regular expenses for customs officers and rafts men salaries [Article XVIII, OeStA/FHKA SUS Patente 65.5 (1733)], certain additional expenses (Unkosten), rent, repairing and building customs objects, purchase of stationery and travel expenses, although some of these expenses were related to people not connected to customs services in any way (Pecinjački 1983, 81).

Economic circumstances shaped the policy of the Habsburg Monarchy, so after the wars of 1683-1699 and 1716-1718 and with stabilized supplies of basic foodstuffs to the domestic market, it was decided that a commercial breakthrough towards the East would be achieved (Tremel 1969, 247). The economic links between the Habsburg lands and the Levant dated back to the Middle Ages, and trade later continued between the Habsburg lands and the East, with the Danube playing an important role in it. In the $17^{\text {th }}$ century the prevalent opinion was that the state should encourage and protect manufacturing and commerce. One of the ways to achieve that was cooperation between the state and individuals who were given privileges and monopoly positions.

The activities of the Oriental company were linked to the functioning of customs in all imperial lands primarily because, during its existence (1719-1741) (Bowman 1950, 31), it was given plenty of privileges through imperial decrees and bylaws [OeStA/FHKA SUS Patente 50.30. (December 29, 1719)]. One of the most important was the right to export all allowed articles to the Ottoman Empire and other neighboring countries by water or by land without payment of customs duties, and establishment of warehouses in Vienna, Belgrade and other places according to its needs (Elibol and Küçükkalay 2011, 163; Aristidu 1978/1979, 263). When importing Turkish merchandise, the company paid customs duties at a rate of $3 \%$ of the merchandise value and $1 \%$ transit duty for goods transported via Vienna to other parts of the monarchy. For raw materials imported from the Ottoman Empire that were needed for production in the factories founded by the Oriental company, customs duties were not paid [OeStA/FHKA SUS Patente 52.21 (May 27, 1719)] (Tschugguel 1996, 50-51). Final products from the Monarchy mostly belonged to the category of luxury products, such as glass, Czech fabric and Hungarian wine, so their sales in the Eastern market had to be encouraged, because goods in demand with imperial 
subjects were imported from there, such as baize, silk materials, spices, rice and tea (Tschuguel 1996, 40-41).

The best indicator of the great influence that the Oriental company had in the Kingdom of Serbia can be seen from the monopoly it had in the trade of honey and wax, so it had the right to establish purchase prices for these articles (Popović 1950, 87-88). That discouraged the population from getting involved in bee-keeping, which used to be one of best developed industries, and enabled development and substantial income [OeStA/FHKA AHK HF Ungarn Sieb. Kaalvhd., Fasz. 99, 233]. In order to prepare customs officers for the implementation of the economic policy of the Monarchy, which doubtlessly included the preservation of privileges given to the Oriental company and some other issues, a decree that regulated these matters was published. Almost simultaneously with the appearance of the customs tariffs book for products and animals, all customs services in the Newly acquired lands received identical instructions for customs officers. These instructions contained forty-one articles and described in detail the rules how officers should act in particular situations. Introduction of the decree stated the purpose and method for the calculation of import, export and transit duties. Hereby we list some of the key regulations that officers had to follow and that were specific for the period discussed [OeStA/FHKA SUS Patente 65.5. (1733);OeStA/FHKA SUS Patente 66.6. (1733)].

\section{PREVENTION OF SMUGGLING}

As learnt from previous experience, in the instructions more attention was paid to procedures aimed at stopping goods smuggling. The decree that specified punitive policies for merchants involved in smuggling was issued as early as 1720 [OeStA/FHKA SUS Patente 51.15. (September 18, 1720)]. That task required the engagement of other administrative services primarily in order to mark routes that merchants had to use, leading towards each customs house in the Kingdom of Serbia. Those merchants who disobeyed these regulations and were caught smuggling goods were fined (contraband) by customs services or some supervisor in that service (they were authorized to do so), and additionally a report was submitted to a competent service (The punishment for smuggling goods and animals could include confiscation, i.e. seizing of the above mentioned. [Articles I and II. OeStA/FHKA SUS Patente 65.5]). Fining for contraband was applicable in cases of smuggling of precious metals (gold and silver), as witnessed by the decrees covering such cases [OeStA/FHKA SUS Patente 52.6. (March 22, 1722); FHKA SUS Patente 57.6. (April 12, 1726)]. One of the principal "operatives" among the state officials of the Monarchy in the Kingdom of Serbia involved in preventing money smuggling was Michael Angelo Hoffman, who was in charge of controlling the content of precious metals in money and its value, and also a clerk of the Imperial money office. His reports from Serbia dispatched to the Court Chamber indicate how widespread money smuggling was, how measures for its prevention were applied and with which money it was allowed to purchase Ottoman merchandise [OeStA/FHKA SUS Realien B20, Nr. 78, fol. 145-151. (June 21, 1734)]. Administrations were specifically instructed not to issue permits for bringing domestic money out, if not necessary. The first instruction was that, if the merchant did not possess the merchandise to export, he was encouraged to provide the money of the destination country. All these Monarchy 
instructions were in accordance with the trade treaty with the Porte that stimulated mutual goods exchange, not one-sided import of Ottoman merchandise for money. Still, if the competent administration received a merchant's request for issuing a passport for taking domestic currency out of the country, then both the amount and currency were written down in the passport. No tax was charged for that procedure, and moneybags had to be sealed by the local customs outpost, and on exiting the country at the border outpost a customs officer would open it to compare the content with the passport data [OeStA/FHKA SUS Patente 57.6. (1726)].

Besides merchandise smuggling, people themselves also crossed the border without a passport, and that was also punishable (Hrabak 1991, 83). Otherwise, all Habsburg subjects had to possess passports when travelling (Pavlović 1901, 17), regardless if they were Austrians or Serbs, and such passports were issued by the administration.

A special case of customs duties applied to domestic animals that were often being taken from the Ottoman Empire to pastures in the Kingdom of Serbia [Article XIII, OeStA/FHKA SUS Patente 65.5. (1733)]. Customs officers made a special pasture certificate (Weyd-Geld), for each individual cattle owner in addition to other custom certificates, and such a certificate was noted in a separate register, where data on the owner, day, month and year of entering the country and how many heads of cattle were taken to pasture were recorded. After grazing was over and the owner left the country with his cattle, the customs officer was obliged to compare the number of heads of cattle from the certificate with the actual number, and if the actual number was smaller, the owner would have to pay import duty, and if the number was bigger, the export duty for appropriate number of heads. Anyway, since it was usual that sheep would lamb offspring during grazing, customs officers charged declared export tariffs for lambs [Article XIII, OeStA/FHKA SUS Patente 65.5. (1733)].

Regardless of if it was import, export or transit, the value of domestic animals (apart from expensive horses) [OeStA/FHKA SUS Patente 65.2. (1733)], was not specified in the tariff books, but customs officers estimated their value that was not less than the specified ones: oxen 12 forints each, cows 7 forints, calves up to one year of age 3 forints each, goats and sheep 1 forint each, piglets 2 forints, pigs 4 forints, bad or old horses 5 forints each, horses in decent shape 10 forints, foals between 2.5 and 5 forints [Article III, OeStA/FHKA SUS Patente 65.5. (1733)].

In wartime, the procedures and transport for foodstuff were different to those in peacetime. To meet the needs of Austrian soldiers in the war against the Ottomans (17371739), a decree was issued on free transport of foodstuff to the Kingdom of Serbia in July of 1737 [OeStA/FHKA SUS Patente 70.15. (July 26, 1737)]. It specified that it was necessary to transport foodstuffs under the best possible conditions, so they would be available to each soldier and also used to make reserves of basic articles such as flour, peas, lentils, rice and other non-perishable and dry edible products, while the intention was that they should be of domestic origin. Along with drinks of an unspecified kind, all the goods were transported by the Danube to Belgrade, and from there towards garrisons in the south. They were exempted from any customs duties and taxes, and the Court Chamber urgently and secretly informed all custom services of that [Article XXXIII. OeStA/FHKA SUS Patente 65.5. (1733)]. According to an imperial resolution on defining the status of domestic militia and hajduks of 1717 , the mentioned armed forces paid only a small part of regular customs tariffs. Those instructions did not specify what percentage was to be paid, 
but emphasized that rules applied to "different goods and wine" [Article XXXIII. OeStA/FHKA SUS Patente 65.5. (1733)].

For many reasons, the population of the Kingdom of Serbia was exposed to epidemics of communicable diseases, primarily of the plague. As a borderline region, it accommodated many soldiers, merchants and travelers from all parts of both empires who were, as ordinary citizens and clergy, victims of this dreadful disease. That had a substantial impact on the intensity of trade volume, and therefore affected the work of customs officers and physicians of the Court Sanitary Commission in quarantines. An epidemic of the plague noted in the Kingdom of Serbia between 1719 and the end of Austro-Turkish War (1737-1739) forced the Habsburg authorities to introduce prevention measures on the border with the Ottoman Empire, in a fashion of those that Venice had applied (Stanojević 1973, 937-942; Pešalj 2005, 590-595; Popović 1950, 386-387; Hrabak 1991, 86; Milošević 2012, 62-68; Pešalj 2011, 181).

The decree that specified in detail the method of work for quarantines at the borders of the Habsburg Monarchy in times of the plague epidemic was issued by the Court Sanitary Commission on October 3, 1731. It described procedures of inspection and clearing of goods, such as treating the whole surface of letters or documents with warm acetic acid, then washing coins with soap or salt, washing or cleaning fabaceous fruits, coffee, rice and bags used to transport the mentioned commodities. These products were to spend three weeks in quarantine, but unlike them, processed and unprocessed hides and leather dressing articles, rough woolen fabrics, thread fabrics, cotton, silk, linen fabrics, muslin and fabrics from animal hairs had to spend six weeks in the open, unpacked [OeStA/FHKA SUS Patente 63.7. (October 3, 1731); OeStA/FHKA SUS Patente 72.11. (October 5, 1738)].

\section{CONCLUDING REMARKS}

The proper and honest work of customs officers was a very important segment in the customs institution, partly in order to increase the income of the treasury, and partly due to the necessity of the first stop after crossing border showing the full progressiveness of the Habsburg Monarchy. That was one of the ways to attract the Christian population as much as possible from the Ottoman Empire to settle in one of the Newly acquired lands. All honest customs officers were urged to indicate all irregularities of their colleagues if they notice them. Customs officers were also performing duties outside the scope of their work. As state employees they had a wider social responsibility. Although that can be regarded as a need to preserve state property, it was clearly defined that customs officers should inform the administration or chief customs authority if they became aware that some chamber clerk, officer or wealthy citizen died without leaving successors, or if his property for whatever reason remained without owner. In such a case, higher Austrian authorities started procedure to transfer the property of the deceased into the treasury [Article XXXVIII and XXXIX. OeStA/FHKA SUS Patente 65.5. (1733)].

After conquering part of Serbia by the end of the Austro-Turkish War, the Habsburg Monarchy undertook quick steps to have this region organized in the fashion of the administrative system in Newly acquired lands (Neoacquistica). In that sense one of the first measures was the organization of a customs service in the Kingdom of Serbia. Its operations, as a part of comprehensive measures by Habsburg authorities to organize that department and make a more efficient system of controlling the flow of people and goods 
from the Ottoman Empire in time included more and more advanced methods. It can be said that this system functioned well for the entire time of the Austrian administration and was based on the implementation of imperial regulations.

Acknowledgement: This paper is a result of archive research conducted in Vienna in 2011 as a part of the projects of the Ministry of Education and Science of the Republic of Serbia The Modernization of the Western Balkans (No. 177099) and The Serbian Nation - Integrative and Disintegrative Processes (No. 177014).

\section{REFERENCES}

Ágoston, Gábor. 'The Ottoman Empire and Europe', in: The Oxford Handbook of Early Modern European History: 1350 - 1750. Vol. II. Cultures and Power. Ed. Hamish M. Scott. Oxford: Oxford University Press(2015): 612-637.

Aristidu, H. Ekaterini. Prilog izučavanju carinskog sistema Dubrovačke republike u XVIII veku, Istorijski časopis 25-26 (1978/1979): 261-268.

Balazs P, Foley K. The Austrian success of controlling plague in the 18th century: maritime methods applied to continental circumstances. Journal of History of Culture, Science and medicine. 1(1) 2010: 73-87.

Baramova, Maria. "Negotiating Borders: Habsburg-Ottoman Peace Treaties of the Seventeenth and Eighteenth Centuries". Edited by M. Baramova, G. Boykov, I. Parvev. In Bordering Early Modern Europe. Berlin: Harrassowitz Verlag, (2015): 115-120.

Barkey, Karen.Empire of difference: the Ottomans in comparative perspective, New York: Cambridge University Press, 2008.

Bowman, Benjamin. Das Mautwesen im 18. Jahrhundert im heutigen Niederösterreich. $\mathrm{PhD}$ diss., Universität in Wien, 1950.

Đorđević, Miloš. „Administration of Belgrade (1720-1738)“. Jahrbuch der österreichischen Gesellschaft zur Erforschung des 18. Jahrhunderts 26 (2011): 185-193.

Elibol, Numan, Küçükkalay, A. Mesud. „Implementation of the Commercial Treaty of Passarowitz and the Austrian Merchants, 1720-1750“. In The Peace of Passarowitz, 1718, edited by C. Ingrao, N. Samardžić, J. Pešalj. Indiana: Perdue University Press, 2011.

Gavrilović, Vladan. „Fragmenti prometnog protokola kontumaca u Paraćinu (1723, 1731. i 1733)“. Mešovita građa 29 (2008): 73-80.

Hajek, Aloise.Serbien unter österreichischen Regierungnach dem Falle Belgrads 1717. Wien, 1912.

Hassinger, Herbert.Johann Joachim Becher, 1635-1682: Beitrag zur Geschichte des Merkantilismus. Wien: A. Holzhausens Nfg., 1951.

Hassinger, Herbert.Geschichte des Zollwesens, Handels und Verkehrs in den östlichen Alpenländern vom Spätmittelalter bis in die zweite Hälfte des 18. Jahrhunderts. Bd 1, Stuttgart: Steiner, 1987.

Hrabak, Bogumil.,„Jevreji u severnoj Srbiji 1688-1739. godine“.Zbornik Narodnog muzeja Čačak XXI (1991): 49-97.

Ingrao, Charles. The Habsburg Monarchy. 1618-1815. Cambridge: Cambridge University Press, 1994.

Jesner, Sabine. "The Physician Adam Chenot - Reshaping Plague Control in the Austrian Cordon Sanitaire (approx. 1770-1780)". Banatica (2015): 283-300.

Kocić, Marija. Dajč Haris. "Kuga u ranomodernom Beogradu: uzroci, strahovi i posledice". Acta hist med stom pharm med vet. 33 (2014):152-161.

Langer, Johann. „Serbien unter der kaiserlichen Regierung (1717-1739)“. In Mittheilungen des k.und k. Kriegsarchivs, neue Folge, 3, Wien 1889.

Milošević, Ana. „Svetačke medaljice iz smederevske tvrđave: prilog proučavanju vizuelne kulture katolika u vreme austrijske vladavine Srbijom 1718-1739“. Smederevski zbornik 3 (2012): 39-70.

Pavlović, Dragoslav. Finansije i privreda za vreme austrijske vladavine u Srbiji. Beograd: Glas SKA 64, 1901.

Peez, Carl von.Die Landsverleger-Compagnia zu Wienn. Die erste Kriegsversorgungs-Gesellschaft 1622-1624. Altösterreichs Handelskompagnien, Bd.1, Wien : Gerlach \& Wiedling, 1918.

Pecinjački, Sreta. „Jedna specifikacija iz 1730. godine o carinskom prometu oršavske i radojevačke carinarnice”. Razvitak XII/2 (1972): 101-103

Pecinjački, Sreta. „Nekoliko podataka o austrijskoj Kraljevini Srbiji od 1731. do 1736. godine“. Zbornik Narodnog muzeja - Čačak X(1980): 97-117. 
Pecinjački, Sreta. „Carinski prihodi i rashodi austrijske Kraljevine Srbije 1730-1732. godine“. Mešovita građa XI (1983): 73-133.

Pešalj, Jovan. „Nadzor i kontrola stranaca u 18. veku. Slučaj Habzburške monarhije“. Beogradski istorijski glasnik II (2011): 177-190.

Pešalj, Jovan. „Između vrača i lekara: obeležja zdravstvene kulture“. In Privatni život u srpskim zemljama u osvit modernog doba, edited by A. Fotić. Beograd: Clio, 2005

Popović, Dušan. Srbija i Beograd od požarevačkog do beogradskog mira (1718-1739). Beograd: Srpska književna zadruga, 1950.

Rifaat A. Abou-el-Haj, 'The Formal Closure of the Ottoman Frontier in Europe: 1699- 1703,' Journal of the American Oriental Society 89/3 (1969): 467-475.

Samaržija, Zdenko. Habzburško vojno zdravstvo u Slavoniji i Srijemu do ukidanja Vojne krajine, Actahist. med. stom. pharm, med. vet. 32 (2013): 95-119.

Stanojević, Gligor. Epidemija kuge u Srbiji 1719. godine i preventivne mjere u Veneciji, Srpski arhiv za celokupno lekarstvo 11-12 (1973): 937-942.

Tremel, Ferdinand.Wirtschafts- und Sozialgeschichte Österreichs. Wien: Deuticke, 1969

Tschugguel, Helga. „Österreichische Handelskompagnien im 18. Jahrhundert und die Gründung der Orientalischen Akademie als ein Beitrag zur Belegung des Handels mit dem Orient “, PhD diss., Universität in Wien, 1996.

Živojinović, Dragoljub. Uspon Evrope (1450-1789). Beograd: Službeni list SRJ, 2000.

UNPUBLISHED ARCHIVE MATERIALS

AUSTRIAN STATE ARCHIVE (ÖSTERREICHISCHES STAATSARCHIV), VIENNA

FHKA (Finanz- und Hofkammerarchiv) SUS Patente 52.21. Gründungspatent einer Orientalischen Handelsgesellschaft auf Grund des Friedens von Passarowitz. (May $27^{\text {th }}, 1719$ )

FHKA SUS Patente 50.30.Neufassung der Statuten der Orientalischen Handelsgesellschaft. (December 29 ${ }^{\text {th }}, 1719$ ).

FHKA SUS Patente 51.15. Strafpatent gegen die Einfuihrung verschiedener Waren auf Nebenwegen. (September $18^{\text {th }}$, 1720)

FHKA SUS Patente 52.6. Silberlegierung und -verkauf in Österreich. (March $22^{\text {th }}, 1722$ )

FHKA SUS Patente 52.14. Patent zur Intensivierung des Schiffbaus und damit der Orientalischen Kompagnie.(May $20^{\text {th }}, 1722$ )

FHKA SUS Patente 57.6.Münzpatent für Slavonien, Banat und Serbien. (December $\left.4^{\text {th }}, 1726\right)$

FHKA SUS Patente 63.7Kontumaz und Reinigungsordnung für die östliche Reichsgrenze (Quarantäne). (October $3^{\text {rd }}, 1731$ )

FHKA SUS Patente 65.5. Instruktionen für die im Temesvarer Banat amtierenden Mautbeamten. (1733)

FHKA SUS Patente 66.6. Instruktion für Mautbeamte in Slawonien. (April 1733)

FHKA SUS Patente 65.2. Mauttariffe für Serbien. (1733)

FHKA SUS Realien B20, Nr. 78.Bericht des M.A.Hoffmann, k.k. Münzprobierer in Serbien.(June 21 $\left.{ }^{\text {st }}, 1734\right)$

FHKA SUS Patente 72.11. Kontumaz- und Reinigungsordnung für die südlichen und östlichen Gebiete. $\left(\right.$ October $\left.5^{\text {th }}, 1738\right)$

\section{TRGOVINA I CARINSKA SLUŽBA NA OSMANSKO-HABZBURŠKOJ GRANICI U PRVOJ POLOVINI 18. VEKA}

U godini u kojoj se obeležava 300-godišnjica potpisivanja Požarevačkog mira (1718), ovaj rad ima za cilj da pruži do sada nepoznate činjenice o trgovini i organizaciji carinske službe u novoosnovanoj austrijskoj provinciji Kraljevstvu Srbiji. Raspolaganje prihodima od carina bilo je u rukama Glavne carinske uprave u Beogradu. Time su pokrivani troškovi njenog rada i punila kasa Administracije. Način rada carinskih službenika bio je uređen posebnim patentima cara Karla VI koji su se odnosili na primenu carinskih tarifa, postupke pri carinjenju robe, uvođenje privilegovanog položaja za Orijentalnu kompaniju, kao i sprovođenje mera zaštite od kuge na granici sa Osmanskim carstvom.

Ključne reči: Habzburška monarhija, carina, trgovina, Osmansko carstvo, Beogradska administracija. 